\title{
CHEMICAL THREATS \\ IN THERMALLY PROCESSED TRADITIONAL FOOD AND POSSIBILITIES OF THEIR REDUCTION ${ }^{1}$
}

\begin{tabular}{|c|c|}
\hline \multicolumn{2}{|c|}{ Warsaw School of Tourism and Hospitality } \\
\hline \multicolumn{2}{|c|}{ Corresponding author: e-mail: jozef@jozefgrochowicz.com } \\
\hline ARTICLE INFO & ABSTRACT \\
\hline $\begin{array}{l}\text { Article history: } \\
\text { Received: November } 2018 \\
\text { Received in the revised form: } \\
\text { December } 2018 \\
\text { Accepted: February } 2019 \\
\end{array}$ & \multirow{2}{*}{$\begin{array}{l}\text { The objective of the paper is to review the present state of knowledge } \\
\text { on health threats that occur as a result of some thermal processing of } \\
\text { food products. Depending on the type and properties of raw materials } \\
\text { and conditions of processes, carcinogenic, mutagen and genotoxic sub- } \\
\text { stances may be formed out of them, which may be treated as a process } \\
\text { contamination. They are produced in processing plants, where their } \\
\text { content is obligatorily controlled and organic, as well as in the condi- } \\
\text { tions of food production in gastronomic units and households. The pa- } \\
\text { per emphasises the second area of food processing, in particular, house- } \\
\text { holds and popularised grilling processes, where there are no other } \\
\text { possibilities of control of the threat level and awareness of people who } \\
\text { prepare food and consumers is insufficient. The paper presents the most } \\
\text { often occurring hazardous compounds, the most important regulations } \\
\text { and admissible limits of consumption, as well as principles of thermal } \\
\text { processing in a safe manner, and possibilities of limiting the levels of } \\
\text { those substances in products. }\end{array}$} \\
\hline $\begin{array}{l}\text { Key words: } \\
\text { food, } \\
\text { thermal processing, } \\
\text { toxic compounds, } \\
\text { food safety }\end{array}$ & \\
\hline
\end{tabular}

\section{Introduction}

There are not many food raw materials, which are consumed in a natural form, without processing (fruit, some vegetables, honey and milk in agri-tourism), while the rest is subjected to various mechanical operations and thermal processing. All those treatments take place because of two reasons: firstly, they change physical and sensory properties of raw materials and secondly, eliminate pathogenic micro-organisms, ensuring health safety to consumers.

As long as mechanical processing (cleaning, washing, removal of inedible parts, fragmenting, mixing etc.) is usually carried out in the temperature of the surrounding and changes only physical properties of the product, not causing any threats to consumers' health, thermal processing carried out usually in temperatures exceeding $100^{\circ} \mathrm{C}$ causes various changes in the heated product, not only textural and sensory, but also chemical leading to formation of

\footnotetext{
1 The paper was written as a part of a defined purpose subsidy for scientific research SGTiR 217906/E-
} $7165 / 2017$. 
new substances, that are a threat to health. These may be only thermal processes, as drying of loose and leaf products, in particular non-membrane, microwave and infrared heating, roasting (e.g. of coffee), cooking, smoking, frying, baking, or grilling, they may be also associated with mechanical processing as pressure agglomeration, conditioning or extrusion.

Their positive effect is elimination of microbiological threats.

The most dangerous compounds, thermally induced in products include:- polycyclic aromatic hydrocarbon, including benzo(a)pyrene, - heterocyclic aromatic amina (HCA), 3-monochloropropanodiol (3-MCPD) and glycide esters of fatty acids, - acrylamide.

Analysis of chemical threats generated in thermal processes should make us consider that this is not the only source of carcinogenic threat. Carcinogenic substances are common in a natural environment and may get to food from soil (Fismes et al., 2002 ), atmosphere (AbdelShafy and Mansour, 2016; Harrison et al., 2018) and contaminated water.

Then, these compounds may be transformed by intestinal microorganisms also dangerous for human health.

The paper presents a current state of knowledge:

- on contaminations and chemical threats generated only as a result of thermal food processing, on legal regulations that determine admissible norms of daily consumption of hazardous substances,

- on the methods of lowering their hazardous nature without going into details of toxicological aspects of a mechanism of their formation and biochemical transformation.

A common feature of those compounds is a carcinogenic threat but each of them usually has also mutagenic and genotoxic impact. For majority of them, legislature provided admissible levels of content in products or admissible levels of daily consumption which are systematically tightened. These processes are investigated since the 1980's and their rate is clearly increasing.

Figure 1 presents number of publications in the world in 1997-2017 concerning only PAH (Sun et al., 2019). It shows that their number exceeded 1100 but increased from 11 in 1997 to 127 in 2017. It should be emphasised that in Poland still there are not many people who pay attention to threats which may occur during the process, which not always results from the lack of knowledge but often from ignoring the health threat (Zachara et al., 2017).

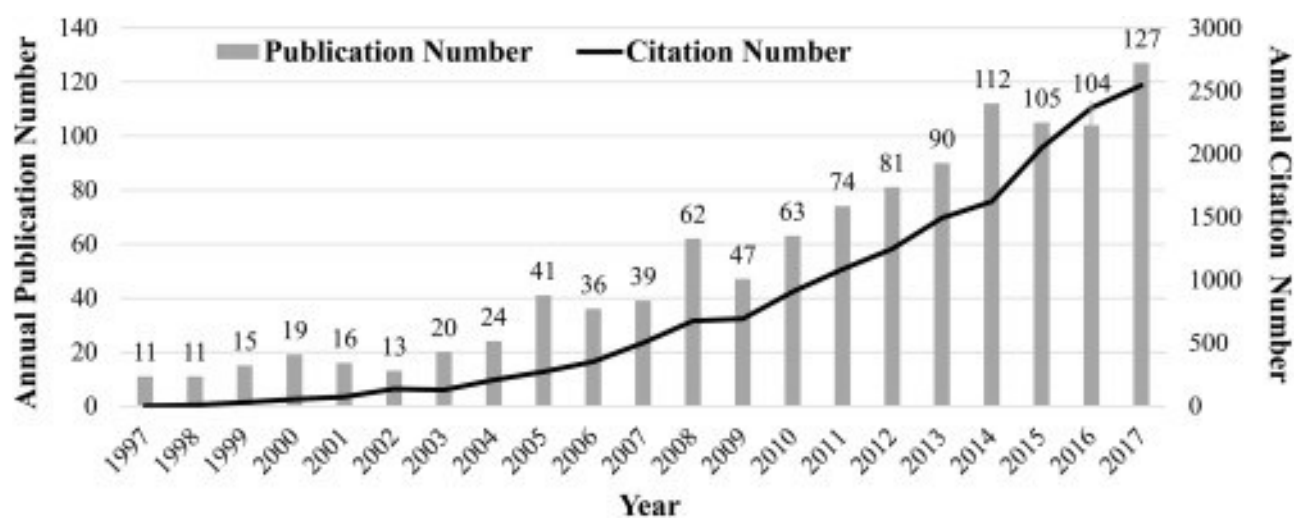

Figure 1. Number of publications on PAH in 1997-2017 (Sun et al., 2019) 
Chemical threats...

Despite clear, proved health threats, there is still scarce knowledge and awareness on the scope of these threats and on possibilities of their reduction, significant during processes where temperature of processing exceeds $120^{\circ} \mathrm{C}$. Frying, particularly grilling, that is performed improperly, may constitute a health hazard.

\section{Polycyclic aromatic hydrocarbons}

PAHs are formed during thermal processing of food products, especially of meat products, in the wide range of temperatures from $125^{\circ} \mathrm{C}$ to $900^{\circ} \mathrm{C}$, in conditions of incomplete combustion of organic materials (Min et al., 2018).

Production of PAHs in products clearly depends on parameters and conditions in which thermal processing is carried out, but the higher the temperature and the longer is the process, the higher is PAH content (Zachara et al., 2017). The raw material and process type, heat sources and heat exchange type, distribution of products towards a heat source are very important, as well as the fat content in meat (Kamal et al., 2018; Wang et al., 2018).

According to WHO as much as $99 \%$ of $\mathrm{PAH}$ in a human body results from consumption of thermally processed food (meat products, fish and sea fruit, grains, leguminous, fats, vegetables, nuts and stimulants), $0.9 \%$ of compounds get to the body with breathed air and only $0.1-0.3 \%$ with drinking water. The biggest number of PAHs are brought to a diet by grain products, processed meat and vegetable oils (Kubiak, 2013).

In 2002 Scientific Commission on Food EU (SCF 2002) determined a list of various PAHs in in vivo tests as carcinogenic and genotoxic, among which benzo(a)piren was treated as an indicator of the threat level and in 2006 an admissible content of $\mathrm{BaP}$ in selected groups of products was defined (Resolution of the Commission (EC) No. 1881/2006). As a result of further research, it was concluded that the content of other PAHs often exceeds the level of benzo(a)pyrene and may occur also in products where benzo(a)pyrene is absent, thus it cannot be used as an indicator. In 2008, EFSA suggested the use of the total content of four the most important PAHS as an indicator. They included benzo(a)pyrene, benzo(b)fluoranthene and chrysene (EFSA, 2008). In 2011, next to benzo(a)pyrene a new indicator was introduced and e.g. for smoked products the following limits were determined (Resolution of the Commission of the EU no. 835 of 2011):

- meat and meat products and fish meat and fisheries products (BaP and PAH4 respectively in $\left.\mu \mathrm{g} \cdot \mathrm{kg}^{-1}\right)$ : - to 31 August 2014 there was 5.0 and 30.0 and since 1 September 2014 there is 2.0 and 12.0

- smoked sprat loosed and preserved - respectively $5.0 \mu \mathrm{g} \cdot \mathrm{kg}^{-1}$ and $30 \mu \mathrm{g} \cdot \mathrm{kg}^{-1}$, and

- processed food based on grains and food for babies and small children - respectively 1.0 $\mu \mathrm{g} \cdot \mathrm{kg}^{-1}$ and for PAH4 also $1.0 \mu \mathrm{g} \cdot \mathrm{kg}^{-1}$.

Analysis of the available research results of the meat grilling process brings a conclusion that despite differences resulting mainly from properties of raw materials (meat type and fat content) and conditions of processing - discrepancies in the obtained levels of BaP content are not high and do not exceed $5 \mu \mathrm{g} \mathrm{kg}^{-1}$ of meat while excessive baking and burning always results in a sudden raise in $\mathrm{BaP}$. For example, in one of such research, the following results were obtained for poultry meat (Ciemniak 2007):

- meat from thigh - average done from 0.15 to $0.46 \mu \mathrm{g} \mathrm{kg}^{-1}$,

- very well-done meat ...0.73 $\mu \mathrm{g} \cdot \mathrm{kg}^{-1}$,

- in a very burned skin ...> $138.0 \mu \mathrm{g} \cdot \mathrm{kg}^{-1}$. 
From the point of view of a consumer, awareness of the existing threat is very important (Jakobsen et al., 2018; Gong 2018) and knowledge on the methods of limitation of PAH level in the processes of thermal processing of products, which may be achieved by replacement of the high - temperature processes with other, such as stewing, cooking, steaming, - replacing a carbon grill with an electric one (heated from the top would be the best) or a gas one, - avoiding cooking directly over the flame, without smoke from heat, - avoiding combustions of the dripping fat e.g. by using trays selecting meat with a lower fat content, - avoiding too high temperatures and shortening the processing time (thinner meat slices), - avoiding chemical or pitchy tinder. The studies also say that various treatments, such as e.g. marinating meat for 30 minutes in vegetable sand seasonings and even in dark beer (Viegas et al., 2014) may lower the PAH level even by half.

\section{Heterocyclic aromatic amines (HAA)}

HAA are formed during thermal processing in high-protein food in the presence of free amino acids including keratins (Gibis, 2016). Presence of HAAs is mainly reported on the surface of grilled or fried products of animal origin i.e. in meat and fish (Lu et al., 2018) which means that they mainly are produced in the conditions of direct preparation of food. The results show that HAAs show mutagenic potency which favours formation of cancer in intestines and breasts. Presently, we know over twenty five various amines, among which three are considered as the most frequent, i.e. MeIQx (2-amino-3,8-dimetyloimidazo [4,5f]quinoxaline,), PhIP (2-amino-1-metylo-6-fenyloimidazo[4,5-b]pirydyne) i IQ (2-amino-3metyloimidazo [4,5-f]quinoline). In the process of frying and baking of various species of meat, it was concluded that the total HAA concentration is within $1-500 \mathrm{ng} \cdot \mathrm{g}^{-1}$, but rarely exceeds $100 \mathrm{ng} \cdot \mathrm{g}^{-1}$ (Nowak and Libudzisz, 2008). The studies also show that daily consumption of HAA does not exceed $17 \mathrm{ng} \cdot \mathrm{g}^{-1}$ of the body weight. To reduce the risk of HAA formation, various recommendations are found in the literature, partially similar to those provided for PAH, such as: - before grilling, cook meat in an oven or over gas, which will reduce discharge of juices during grilling, - perform the processes in a possibly lowest temperature and short time, avoiding superficial burning, - fry meat along with vegetables that contain active substances, that block formation of HAA, - marinate meat for at least 20 minutes before grilling with various vegetables, seasonings and herbs, such as: onion, garlic, red pepper, ginger, curcuma, rosemary, pepper, marjoram, sage, with olive oil, wine vinegar, beer and wine. Studies on the impact of natural anti-oxidants on reduction of HAA concentration proved that catechins, flavonoids, vitamin $\mathrm{E}$ and other bioactive substances reduced concentration of some HAAs even by 97\% (Majcherczyk and Surówka, 2015; Meurillon and Engel, 2016; Mejborn et al., 2016). It was also concluded that fibre may combine with HAA, thus it is recommended to eat together with grilled meat products that include food fibre.

\section{3-Monochloropropano-1,2-diol (3-MCPD) and glycidol esters of fatty acids}

3-Monochloropropano-1,2-diol (3-MCPD) found in 1978 is one of several chloropropanols, which may form in food during thermal processing. It is produced during oil refinement (especially the palm oil) and during acidic hydrolysis of plant protein (acid-HVP) and 
Chemical threats...

this it is also present in many products, which contain HVP, inter alia, in soya sauces, bouillon cubes, instant soups, RTE foods, frozen meals etc.

Progress showed that these compounds are also present in products that do not contain HVP such as processed cheese and grilled cheese, smoked meat and fish, anchovies in oil and grain products, bread, cookies or instant coffee (Baer et al., 2010).

The EFSA (European Food Safety Authority 2013) report includes results of 1235 analyses collected in EU countries from the studies carried out in 2009-2011. It was proved that the highest number of 3-MPCD was in (on average in $\mu \mathrm{g} \cdot \mathrm{kg}^{-1}$ ) margarine and similar products -1500 plant fats and refined oils -530 , while baked grain products -33 and smoked fish -39 .

Pursuant to EU document (Recommendation of the Commission from 10 September 2014) 3-MCPD was recognised as a potentially carcinogenic process contamination for which daily acceptable intake at the level of $2 \mu \mathrm{g} \cdot \mathrm{kg}^{-1}$ body mass daily was determined. Except of 3-MCPD, glicyde esters of fatty acids occur which were found not only in meat and fat products (sausages, oils) but also in French fries, toasts, cookies, crackers, roasted coffee, etc. (Tomar et al. 2010). Presently, applicable admissible limits of 3-MCPD and glicyde esters content are defined in the Resolution of the Commission (EU) 2018/290 as of 26 February 2018 and are: a/ for 3-MCPD - in hydrolysed plant proteins and soya sauce $20 \mu \mathrm{g} \cdot \mathrm{kg}^{-1}$, $\mathrm{b} /$ for glicyde esters:

- in oils and plant fats designed for consumers $1000 \mu \mathrm{g} \cdot \mathrm{kg}^{-1}$,

- in oils and plant fats designed for children and in grain products processed for infants and small children $500 \mu \mathrm{g} \cdot \mathrm{kg}^{-1}$,

- in preparation for initial feeding of infants in powder 75 and in liquid $10 \mu \mathrm{g} \cdot \mathrm{kg}^{-1}$.

For whom since 1 July 2019 , this limit will be reduced respectively to 50 and $6.00 \mu \mathrm{g} \cdot \mathrm{kg}^{-1}$. In 2016 the presence of 3-MCPD in paper products which are in contact with food (e.g. Coffee filters, tea bags, milk and juices cardboard containers and paper cups) and its penetration to products were investigated (Becalski et al., 2016). It was found out that 3-MCPD was present in majority of them e.g. in tea bags in the amount of a few $\mathrm{ng} \cdot \mathrm{g}^{-1}$. In industrial conditions several possibilities of efficient reduction of 3-MCPD content was developed, while in the conditions of thermal processing of products shortly before consumption, there are the following methods of reduction of 3-MCPD and its esters: reduction of the product processing temperature, particularly at its low moisture content, reduction of the processing time, reduction of the salt content, adding herbs and seasonings or deactivation of enzymes (lipases and esterases) (Crews, 2012; Baer et al., 2010; Kowalska et al., 2015).

\section{Acrylamide}

Acrylamide has a form of white crystalline substance. It has been present in many industrial products (paints, packaging, glues, and cosmetics), it is also used in drinking water filtration systems, it occurs also in cigarette smoke. Only as late as in 2002 it was concluded that acrylamide also appears in many food products. It is formed in reactions which take place between free amino acids, mainly asparagine, and reducing sugars in the temperature above $120^{\circ} \mathrm{C}$ thus during such processes as frying, baking and roasting of carbohydrate products. Acrylamide is a neurotoxic compound but is also recognised as a potentially carcinogenic 
substance and although there is scarce knowledge on threshold limits of its daily consumption, indicators for particular types of food, which should not be exceeded were established (Recommendation of the Commission as of 8 November 2013). Therefore, e.g. Indicators for selected products are (in $\mu \mathrm{g} \cdot \mathrm{kg}^{-1}$ of product): French fries -500 , potato crisps -1000 , fresh wheat bread -80 , biscuits and waffles -500 , gingerbread -1000 , roasted coffee -450 , instant coffee -900 and grain coffee -2000 .

Although, there are publications that indicate carcinogenic activity, it has not been clearly determined what is its daily admissible consumption. According to the WHO report (quoting Mojska and Gielecińska, 2012) based on the research on animals, the risk of a single cancer incidence per 10000 people is caused by continuous consumption of acrylamide at the level of $0.14 \mu \mathrm{g} \cdot \mathrm{kg}^{-1}$ of the body weight daily. In other research, it was concluded that systematic intake of 1 microgram of acrylamide per $\mathrm{kg} /$ of body weight daily is caused by many various sources (Freisling et al.,2013) - potential frequencies of cancer incidence:

- 4,5 person per 1000 (by the U.S. EPA),

- 0.7 per 1000 (by the WHO),

- 10 persons per 1000 (by Stockholm University).

So far, only maximum content of acrylamide in drinking water is defined by law, it is 0.1 $\mu \mathrm{g}$ in 1 litre (Resolution of the Minister of Health as of 29.03.2007 r.)

According to the EFSA report, the research carried out in EU countries in 2007-2009 (EFSA 2011), the average content of acrylamide was within $37 \mu \mathrm{g} \cdot \mathrm{kg}^{-1}$ in bread to $1504 \mu \mathrm{g}$ $\mathrm{kg}^{-1}$ in coffee substitute but the highest reported content for $4804 \mu \mathrm{g} \cdot \mathrm{kg}^{-1}$ in potato crisps. It was assumed that daily consumption according to age groups is (in $\mu \mathrm{g} \mathrm{kg}^{-1}$ of body weight): for adults $0.31-1.1$; for youth (aged 11-17) - from 0.7 to 2.05 ; for children (3-10 years) from 1.2 to 2.4 .

The monitoring research that was carried out, show that exposure of the Polish population to acrylamide that comes from food, is $0.43 \mu \mathrm{g} \cdot \mathrm{kg}^{-1} \mathrm{~m} . \mathrm{c}$ daily.

The following factors influence the reduction of the acrylamide level in food: raw materials: free asparagine and reducing sugars content and applied additives (e.g. in grain products ammonium carbonate raises the level of acrylamide in comparison to the sodium carbonate), technological ones: possibly the lowest temperature (within $120-180^{\circ} \mathrm{C}$ ), short time of thermal processing, low water content (below 30\%), avoiding excessive burning of the final product.

\section{Conclusion}

Thermal processing of food has been used for ages without awareness of possible side effects. Now, we know that practically all components of food are degraded in raised temperatures. Size and character of those changes and their impact on health depends on the type and properties of the heated product, process type, temperature value and processing time.

Detailed and extensive research, carried out in recent years, provide information on even newer degradation products, which may have a hazardous impact on health and constitute threat, mainly with carcinogenic nature. However, confirmation of the level of their harmfulness requires laborious and time-consuming laboratory and clinical research. 
Chemical threats...

New data obtained as a result of the research that was carried out show that admissible thresholds of the content of these substances in food are constantly reduced and simultaneously new methods of limitation of threats are searched for, all the more that many of them occur not only in food but also in exhaust gases, cigarette smoke, cosmetics and even are produced as a result of metabolic rates. Each of the described compounds includes a clear impact on the condition of our health, thus we should remember about their generation in high-temperature processes and possible methods of their reduction in the product (Lu et.al., 2018). According to the review - a lot depends on the consumer's awareness and we should remember about those threats, because they decide on our health and longevity. Regardless, the described threats, thermal processing, especially grilling brings also other threats, among which we mat list: production of nitrosamines in cured meat under the influence of high temperature, furan, acrolein production as a result of combustion and fat smoking on a grill or a frying pan (Stevens et al., 2008; Moghe et al., 2015), or e.g. recently investigated migration of aluminium from foil to grilled products in high temperatures, which requires separate analysis.

\section{References}

Abdel-Shafy, A.L., Mansour, M.S.M. (2016). A review on polycyclic aromatic hydrocarbons: Source, environmental impact, effect on human health and remediation. Egyptian Journal of Petroleum, 25 , 107-123.

Baer, I., de la Calle, B., Taylor, P. (2010). 3-MCPD in food other than soy sauce or hydrolysed vegetable protein (HVP). Anal Bioanal Chem, 396, 443-456.

Becalski, A, Zhao, T., Breton, F., Kuhlmann, J., (2016). 2- and 3-Monochloropropanediols in paper products and their transfer to foods. Food Additives \& Contaminants: Part A. 33(9), 1499-1508.

Ciemniak, A. (2007). Porównanie wpływu metody grillowania na zawartość benzo[a]pirenu w mięsie kurcząt. Żywność. Nauka. Technologia. Jakość, 3(52), 54-61

Crews, C. (2012). Fatty acid esters of chloropropanols and glycidol in foods - analysis and exposure. 1 International Association for Food Protection European Symposium on Food Safety, Warsaw 2123 May 2012.

European Food Safety Authority (2008). Polycyclic Aromatic Hydrocarbons in Food1 Scientific Opinion of the Panel on Contaminants in the Food Chain (Question N ${ }^{\circ}$ EFSA-Q-2007-136) Adopted on 9 June 2008. EFSA Journal, 2008 724, 1-114.

European Food Safety Authority (2011). Results on acrylamide levels in food from monitoring years 2007- 2009, EFSA Journal, 9(4), 2133.

European Food Safety Authority (2013). Analysis of occurrence of 3-monochloropropane-1,2-diol (3-MCPD) in food in Europe in the years 2009-2011 and preliminary exposure assessment. EFSA Journal, 11(9), 3381.

Fismes, J., Perrin-Ganier, C., Empereur-Bissonet, P., Morel, J.L. (2002). Soil-to-root transfer and translocation of polycyclic aromatic hydrocarbons by vegetables grown on industrial contaminated soils. J. Environ. Qual., 31(5), 1649-56.

Gibis, M., (2016). Heterocyclic Aromatic Amines in Cooked Meat Products: Causes, Formation, Occurrence, and Risk Assessment. Comprehensive Reviews in Food Science and Food Safety, 15(2), 269-302.

Gong, G., Zhao, X., Wu, S., (2018). Effect of natural antioxidants on inhibition of parent and oxygenated polycyclic aromatic hydrocarbons in Chinese fried bread youtiao. Food Control, 87, 117-125. 
Harrison, R.M., Jang, E., Alam, M.S., Dang, J. (2018). Mechanisms of reactivity of benzo(a) pyrene and other PAH inferred from field measurements. Atmospheric Pollution Research, May 2018, DOI: 10.1016/j.apr.2018.05.009.

Jakobsen, L.S., Georgiadis, S., Nielsen, B.F. (2018). Probabilistic approach for assessing cancer risk due to benzo[a]pyrene in barbecued meat: Informing advice for population groups. PLoS ONE, $13(11), 45$.

Kamal, N.H.A, Selamat, J., Sanny, M. (2018). Simultaneous formation of polycyclic aromatic hydrocarbons (PAHs) and heterocyclic aromatic amines (HCAs) in gas-grilled beef satay at different temperatures. Food Additives \& Contaminants Part A, 35(5), 848-869.

Kowalska, D., Gruczyńska, E., Kowalska, M., Kozłowska, M., Kowalski, B. (2015). Chloropropanole, chloropropanodiole i ich estry w żywności. Żywność. Nauka. Technologia. Jakość, 4(101), 5-20.

Kubiak, M.S. (2013). Wielopierścieniowe węglowodory aromatyczne (WWA) - ich występowanie w środowisku i w żywności. Probl. Hig. i Epidem, 94, 1, 31-36.

Lee, J.G., Kim, S.Y., Moon, J.S., Kim, S.H., Kang, D.H., \& Yoon, H.J. (2016). Effects of grilling procedures on levels of polycyclic aromatic hydrocarbons in grilled meats. Food Chemistry, 199, 632-638.

Lu, F., Kuhnle, G.K., Cheng Q. (2018). The effect of common spices and meat type on the formation of heterocyclic amines and polycyclic aromatic hydrocarbons in deep-fried meatballs, Food Control, 92, 399-411.

Majcherczyk, J., Surówka, K. (2015). Heterocykliczne aminy aromatyczne jako zagrożenie chemiczne w produktach mięsnych poddawanych obróbce termicznej. Żywność. Nauka. Technologia. Jakość, 1(98), 16-34.

Mejborn H., Biltoft-Jensen A., Hansen M., Rask T., Pelle L., Olesen T., Sørensen I.K. (2016), Mechanisms behind cancer risks associated with consumption of red and processed meat. National Food Institute Division of Risk Assessment and Nutrition 1. edition, Juni 2016.

Meurillon, M., Engel, E. (2016). Mitigation strategies to reduce the impact of heterocyclic aromatic amines in proteinaceous foods. Trends in Food Science and Technology, 50, 70-84.

Min, S., Patra, J.K., Shin, H-S. (2018). Factors influencing inhibition of eight polycyclic aromatic hydrocarbons in heated meat model system. Food Chemistry, 239, 993-1000.

Moghe, A., Ghare, S., Lamoreau, B., Mohammad, M., Barve, S, McClain, C., Joshi-Barve, S. (2015) Molecular Mechanisms of Acrolein Toxicity: Relevance to Human Disease. Toxicol. Sci. Feb; 143(2): 242-255.

Nowak, A., Libudzisz, Z. (2008). Karcynogeny w przewodzie pokarmowym człowieka. Żywność. Nauka. Technologia. Jakość, 4(59), 9-25.

Rozporządzenie Komisji (WE) Nr 1881/2006 z dnia 19 grudnia 2006 r. ustalające najwyższe dopuszczalne poziomy niektórych zanieczyszczeń w środkach spożywczych. Dz. Urz. UE L 364, s. 5, z dnia 20.12.2006 z późn. zm.

Rozporządzenie Komisji (UE) 2018/290 z dnia 26 lutego 2018 r. zmieniające rozporządzenie (WE) nr 1881/2006 w odniesieniu do najwyższych dopuszczalnych poziomów estrów glicydowych kwasów tłuszczowych w olejach i thuszczach roślinnych, preparatach do początkowego żywienia niemowląt, preparatach do dalszego żywienia niemowląt i żywności specjalnego przeznaczenia medycznego dla niemowląt i małych dzieci. Dziennik Urzędowy Unii Europejskiej L 55/27, 27.02.2018

Rozporządzenie Komisji (UE) NR 835/2011 z dnia 19 sierpnia 2011 r. zmieniające rozporządzenie (WE) nr 1881/2006 odnośnie do najwyższych dopuszczalnych poziomów wielopierścieniowych węglowodorów aromatycznych w środkach spożywczych. Dziennik Urzędowy Unii Europejskiej, L 215/4, 20.08.2011.

Rozporządzenie Komisji (WE) Nr 208/2005 z dnia 4 lutego 2005 r. zmieniające rozporządzenie (WE) $\mathrm{nr} 466 / 2001 \mathrm{w}$ odniesieniu do wielopierścieniowych węglowodorów aromatycznych. Dz. Urz. UE L 34, s. 3, z dn. 8.02.2005. 
Chemical threats...

Scientific Committee on Food (2002), Opinion of the Scientific Committee on Food on the risk to human health of Polycyclic Aromatic Hydrocarbons in food. SCF/CNTM/ PAH/29 Final 4 December 2002.

Stevens, J.F., Maier, C.S. (2008). Acrolein: sources, metabolism, and biomolecular interactions relevant to human health and disease. Mol. Nutr. Food Res., 52, 7-25

Sun, Y., Wu, S., Gong, G. (2019). Trends of Research on Polycyclic Aromatic Hydrocarbons in Food: A 20-year perspective from 1997 to 2017, Trends in Food Science \& Technology, 83, 86-98.

Viegas, O., Yebra-Pimentel, I., Martínez-Carballo, E., Simal-Gandara, J., Ferreira, I. (2014). Effect of Beer Marinades on Formation of Polycyclic Aromatic Hydrocarbons in Charcoal-Grilled Pork. $J$. Agric. Food Chem. 62(12), 2638-2643.

Wang, C., Xie, Y., Qi, J., Yu, Y., Bai, Y., Dai, C., Li, C., Xu, X., Zhou, G., (2018). Effect of Tea Marinades on the formation of polycyclic aromatic hydrocarbons in charcoal-grilled chicken wings, Food Control, 93, 325-333.

Zachara, A., Gałkowska, D., Juszczak, L. (2017). Contamination of smoked meat and fish products from Polish market with polycyclic aromatic hydrocarbons. Food Control, 80, 45-51.

Zalecenie Komisji (2014/661/UE) z dnia 10 września 2014 r. w sprawie monitorowania występowania w żywności 2 i 3-monochloropropano-1,2-diolu (2 i 3-MCPD), estrów kwasów tłuszczowych 2 i 3 MCPD oraz estrów glicydowych kwasów tłuszczowych). Dz. U. UE L 271/93 (2014/661/UE).

\section{ZAGROŻENIA CHEMICZNE POWSTAJACE W ŻYWNOŚCI TRADYCYJNEJ OBRABIANEJ TERMICZNIE I MOŻLIWOŚCI ICH OGRANICZANIA}

Streszczenie. Celem opracowania jest przegląd aktualnej wiedzy o zagrożeniach dla zdrowia powstających w wyniku niektórych procesów termicznej obróbki produktów spożywczych. Zależnie od rodzaju i właściwości surowców oraz warunków prowadzenia procesów mogą podczas nich powstawać substancje rakotwórcze, mutagenne i genotoksyczne, które traktowane są jako zanieczyszczenie procesowe. Powstają one zarówno w skali zakładów przemysłowych, gdzie ich zawartość jest obowiązkowo kontrolowana i ograniczana, jak też w warunkach produkcji potraw w zakładach gastronomicznych oraz gospodarstwach domowych. W pracy nacisk jest położony na ten drugi obszar przetwórstwa, zwłaszcza na gospodarstwa domowe i upowszechnione procesy grillowania, gdzie nie ma żadnych możliwości kontroli poziomu zagrożeń, a świadomość osób zarówno przygotowujących potrawy, jak i konsumentów jest niedostateczna. Przedstawiono tutaj najczęściej występujące szkodliwe związki, najważniejsze regulacje prawne i dopuszczalne limity spożycia, a także zasady prowadzenia procesów obróbki termicznej w sposób bezpieczny dla zdrowia, także możliwości ograniczania poziomu tych substancji w produktach.

Słowa kluczowe: żywność, obróbka termiczna, związki toksyczne, bezpieczeństwo żywności

Identification data Authors:

Józef Grochowicz https://orcid.org/0000-0003-1539-3065 